\title{
A comparative study of the acoustic characteristics of the vowel /a/ between children with spastic and dyskinetic cerebral palsy
}

\author{
Pil Yeon Jeong ${ }^{1} \cdot$ Hyun Sub Sim ${ }^{2, *}$ \\ ${ }^{1}$ Ewha Womans University Center for Child Development and Disability, Seoul, Korea \\ ${ }^{2}$ Department of Communication Disorders, Ewha Womans University, Seoul, Korea
}

\begin{abstract}
This study aims to compare the acoustic characteristics of vowel phonation in children with spastic and dyskinetic cerebral palsy (CP). Thirty-four children aged 4-12 years with CP participated in the study (spastic 26, dyskinetic 8). Voice samples for the acoustic analysis were extracted from a sustained vowel /a/. All acoustic measures were made using Praat. Group differences were compared by an independent $t$-test or Welch-Aspin test, if the equivalence assumption was not met. The results of this study are as follow. First, maximum phonation time(MPT) was significantly shorter for the dyskinetic CP than for the spastic CP. Second, shimmer percent was significantly increased in the dyskinetic CP than in the spastic CP. Lastly, there were no significant group differences in both the first formant and the second formant. These findings indicate that the dyskinetic $\mathrm{CP}$ has a poorer respiratory capacity and poorer laryngeal function than the spastic CP. On the other hand, both groups have a comparable ability to articulate the vowel /a/. The results of the present study help speech language pathologists identify the speech motor control ability of children with two types of CP (spastic and dyskinetic) and help to make an intervention plan associated with a specific type of CP.
\end{abstract}

Keywords: cerebral palsy, MPT, Jitter, Shimmer, noise to harmonic ratio (NHR), formant frequency

\section{1. 서론}

뇌성마비는 뇌의 미성숙한 발달 또는 발달 중의 뇌손상으로 인한 운동장애 및 자세의 장애로 정의되며(Workinger, 2005) 운 동장애 유형에 따라 경직형, 불수의운동형, 운동실조형, 혼합형 등으로 분류된다(Minear, 1956; Workinger, 2005). 경직형과 불수 의운동형의 비율이 높은데(Kudrjavcev et al., 1983; Pharoah et al., 1987), 경직형의 병변은 추체로이고, 불수의운동형은 추체외로
로 운동장애 양상에서 차이를 보인다. 경직형은 움직임이 느리 고 뺏뻣한 특징을 보이는 반면 불수의운동형은 의도적인 움직 임을 시도할 때 불수의적인 움직임을 보인다(Marks, 1974).

유형에 따라 말산출 양상에서도 차이를 보이는데 호흡과 발 성에서 분명한 차이가 있다고 보고되고 있다(Hardy, 1983; Nam, 2015; Nordberg et al., 2014; Salmon \& Charron, 1998). 호흡능력 의 손상은 경직형보다 불수의운동형에서 더 심한 양상이 나타 나는데(Love, 2000; Salmon \& Charron, 1998), 불수의운동형 뇌

\footnotetext{
*simhs@ewha.ac.kr, Corresponding author

Received 31 January 2020; Revised 15 March 2020; Accepted 16 March 2020

(C) Copyright 2020 Korean Society of Speech Sciences. This is an Open-Access article distributed under the terms of the Creative Commons Attribution NonCommercial License (http://creativecommons.org/licenses/by-nc/4.0) which permits unrestricted non-commercial use, distribution, and reproduction in any medium, provided the original work is properly cited.
} 
성마비 아동은 안정 상태와 말산출 과정 모두에서 호흡에 문제 를 보인다(Salmon \& Charron, 1998). 예를 들면, 호흡 속도가 빠 르며(Hardy, 1983) 흡기 시 소음(audible inspiration)이나 호기 끝 부분에서 그렁거림(grunt at end of expiration) 증상을 보인다 (Nam, 2015).

발성에서도 유형 간에 차이를 보이는데, 불수의운동형에서 는 후두기류의 밸빙이 불안정하고, 경직형은 성문하압을 안정 적으로 유지하기 어렵다(Workinger, 2005). 후두계의 손상으로 인한 문제는 불수의운동형에서 더 많이 나타나는데, 경직형에 비해 발성을 시작할 때 불필요한 예비발성(prevocalization)이 더 빈번하게 나타나고(Farmer \& Lencione, 1977), 음도가 더 높으 며, 음도변화가 자주 나타난다(Duffy, 1954). 또한 강도파열 (loudness break), 음도파열(pitch break), 음성진전(voice tremor) 등이 불수의운동형에서 더 빈번하게 나타난다(Nam, 2015). 경 직형은 기식성의 음질, 단음도, 단강도를 특징으로 하는 데 비 해, 불수의운동형은 부적절한 음성의 끊김과 이완을 특징적으 로 보인다(Kent \& Netsell, 1978). 이러한 차이는 경직형에 비해 불수의운동형에서 호흡과 성대운동의 불수의적 변화가 더 많 이 나타나기 때문이다.

뇌성마비 유형에 따라 구분되는 음성문제를 이해하기 위해 서는 청지각적인 분석과 함께 음성분석 기기를 활용한 객관적 인 평가가 필요하다. 청지각적 평가는 임상현장에서 보편적으 로 실시되고 있고, 시간과 절차적 측면에서 장점이 있으나 주관 적 판단에 의존하기 때문에 평가자 간 신뢰도에서 변산성이 높 다는 한계가 있다(Bang et al., 2013). 음성의 음향학적 분석은 사 운드 스펙트로그래프를 이용하여 음성의 음향학적 구조를 시 각적으로 판별하는 검사로서(Ahn, 1995), 음성의 물리학적 특성 에 대한 객관적 정보를 제공해 준다(Bhuta et al., 2004). 또한 비 침습적(non-invasive) 방법으로 음성장애를 수량화하여 객관적 으로 측정할 수 있으며(Bang et al., 2013) 음성치료 전후 호흡 및 발성 양상의 변화를 정밀하게 확인할 수 있다는 장점이 있다.

뇌성마비 아동의 음성적 특성은 단순히 성대의 움직임에 의 한 음성 산출만을 통해 설명할 수는 없다(Lee, 2004). 즉 뇌성마 비 아동의 음성문제는 비대칭적 자세와 움직임, 근긴장성, 흥곽 의 구조와 기능 및 호흡패턴 등과 관련되어 있기 때문에(Lee, 2004) 병리적 음성을 호흡과 발성차원에서 분석하기 위해 다양 한 음향학적 파라미터들을 측정한 여러 연구들이 실시되었다 (Lee, 2004; Nam \& Kwon, 2009; Park et al., 2004; Park et al., 2007). 발성 동안 호흡에 문제가 있는가를 확인을 위해 MPT (Maximum Phonation Time; Jeong et al., 2011)가 사용되고 있고, 음성을 음향학적으로 측정하기 위해 F0, Jitter, Shimmer, NHR (Noise to Harmonic Ratio) 측정치 등이 사용되고 있다(Park et., 2004). F0는 기본적인 음도에 대한 물리음향학적 측정치이고, Jitter는 음도의 불규칙성을, Shimmer는 음성강도의 불규칙성을 반영한다. Jitter와 Shimmer는 음성의 안정성을 살펴보는 요소로 성대 간 비대칭성, 기류 흐름의 문제, 성대 점액질의 작용, 모세 혈관의 분포 등에 의해 영향을 받는다(Martin et al., 1995). NHR 은 음질의 특성과 관련성이 있어서 병리적인 음성에 대한 음향
물리학적 측정치로 수치가 높을수록 음성문제가 있는 것으로 본다(Martin et al., 1995). NHR은 후두 내부근육의 과다한 수축 과 관련이 있는데(Boone et al., 1988), 소음 에너지에 비해 배음 에너지가 더 많아야 정상적인 음성으로 지각되며 기식화되거 나 쥐어짜는 듯한 음성에서는 배음 에너지가 감소되고, 소음 에 너지는 증가한다고 본다(Yumoto et al., 1984).

또한 모음은 성도의 모양에 따라 고/저모음, 전설/후설모음 등으로 구분되는데, 이 기준은 상대적이고, 조음기관의 크기나 혀의 위치 등이 완벽하게 일치하지 않는다. 따라서 Ladefoged (2006)는 공명 주파수를 사용하여 모음의 음향학적 자질을 분류 할 것을 제안하였다. 공명 주파수는 모음 산출에 있어 혀의 높 이와 위치에 민감하게 반응하기 때문에(Fry, 1979), 모음의 정확 한 위치나 모음 오류를 분석하는데 공명주파수를 이용한 분석 이 효과적이다(Park, 2008). 특히 F1과 F2는 구강 내 혀의 전후 및 고저 자질에 관한 정보를 제공해 주기 때문에(Lee et al., 2002), F1과 F2를 측정함으로써 모음 산출 시 조음운동의 특성을 간접적으로 파악할 수 있다(Fry, 1979; Ladefoged \& Broadbent, 1957). 위에서 언급한 음향학적 측정치를 뇌성마비 치료 전후비 교를 했을 경우, 치료 후에 Jitter와 Shimmer, NHR 값이 감소하 고, 음성강도가 증가했다면 이는 호흡 및 발성의 조절능력이 향 상되었음을 보여주며(Brockmann et al., 2008), F1과 F2의 측정치 가 정상치에 근접했다면 모음산출능력이 향상되었음을 보여주 는 것으로 해석할 수 있다.

뇌성마비 아동을 대상으로 한 국내 선행연구를 살펴보면 다 음과 같다. 뇌성마비 아동과 일반아동 간의 음향학적 특성을 분 석한 Park et al.(2007)과 Park et al.(2004)의 연구는 경직형 뇌성 마비 아동이 일반아동에 비해 MPT, Jitter, Shimmer, NHR의 측 정치에서 집단 간 차이가 있음을 보고하였다. 이러한 연구결과 는 일반아동에 비해 경직형 뇌성마비 아동의 호흡능력이 저하 되어 있고, 미숙한 성대조절능력으로 인해 발성기능이 저하되 어 있음을 시사한다.

한편 뇌성마비 유형 간에도 발성의 음향학적 차이를 분석한 연구가 있다(Lee, 2004; Nam \& Kwon, 2009). Nam \& Kwon(2009) 은 생활연령 9 39세의 뇌성마비 화자를 대상으로 경직형과 불 수의운동형 간에는 Jitter, Shimmer 및 HNR에서 유의한 차이가 없다고 보고하고 있다. 6 11세의 경직형과 무정위운동형 뇌성 마비 아동을 대상으로 한 Lee(2004)의 연구는 모음 '아' 산출 시 에 나타난 음향학적 측정치 F0, Jitter, Shimmer, NHR에서 유형 간에 유의한 차이는 없다고 보고하였다. 이 2 개의 연구결과에 의하면 유형별로 차이가 없는 것 같으나, 평균값을 살펴보면 유 형 간에 차이가 있음을 확인할 수 있다.

위에서 언급한 국내 선행연구들을 비교분석해 보면, 경직형 뇌성마비 아동의 모음 산출 시 음향학적 특성을 일반아동과 비 교하였고(Park et al., 2004; Park et al., 2007), 아동 및 성인 뇌성 마비화자를 대상으로 유형별 차이에 대한 연구가 시도되었지 만(Lee, 2004; Nam \& Kwon, 2009) 연구결과는 일관적이지 못하 다. 경직형 뇌성마비와 일반집단을 대상으로 F1과 F2의 집단 간 비교 연구가 진행되었고(Lee et al., 2002; Park et al., 2004; Park et 
al., 2007), 정상아동과 경직형, 불수의운동형 및 혼합형의 뇌성 마비 유형 간의 비교 연구가 이루어지기도 하였으나(Sim \& Park, 1998) 후속연구가 매우 드문 실정이다.

뇌성마비 아동의 말산출 특성을 청지각적으로 분석해 보면 유형 간에 유사한 특성들이 중첩되기도 하는데(Love, 2000; Nam \& Kwon, 2009; Workinger \& Kent, 1991), 음향학적 분석을 실시한다면 발성이나 음질, 조음산출과정의 특성들을 정량화 하여 비교해 볼 수 있을 것이다. 임상에서는 대부분 청지각적 방법으로 평가를 실시하고 있으나, 신뢰도와 객관성의 문제를 보완하기 위해 음향학적 평가의 필요성을 제기하고 있다. 또한 뇌성마비 유형의 출현율은 경직형과 불수의운동형의 비율이 다른 유형에 비해서는 높은 편이나 경직형 뇌성마비아동을 대 상으로 한 연구가 많았고, 경직형과 불수의운동형 뇌성마비 아 동 간 비교 연구는 상대적으로 드문 편이었다. 따라서 본 연구 에서는 경직형과 불수의운동형 뇌성마비 아동 간에 /아/ 모음 산출 시 다음과 같은 음향학적 파라미터를 통해 그 특성을 비교 하고자 하였다. MPT, F0, Jitter, Shimmer, NHR, F1, F2. 이를 통 해 뇌성마비 유형별 호흡과 발성능력의 차이를 살펴보고(MPT), 후두수준에서의 음질이나 발성상태를 비교해 보며(F0, Jitter, Shimmer, NHR), 모음 조음 시 나타나는(F1, F2) 유형 간 차이에 대해서 알아보고자 하였다.

\section{2. 연구방법}

\section{1. 연구대상}

본 연구에는 1) 성대의 구조적, 기질적인 이상이 없다고 보고 한 2) 생활연령 만 4 12세의 3) 부모보고나 차트검토를 통해 경 직형 또는 불수의운동형 뇌성마비로 확인된 34명(경직형 26명, 불수의운동형 8명)의 아동이 참여하였다. 언어능력에 대한 평 가는 Kim et al.(2010)의 수용 및 표현어휘력 검사(Receptive \& Expressive Vocabulary Test, REVT) 가운데 수용어휘력 검사를 실 시하였다. 자음정확도는 Kim et al.(2007)의 아동용 발음평가 (Assessment of Phonology \& Articulation for Children, APAC)를 사용하여 측정하였다. 표 1 에 연구대상의 평균연령, 연령범위, 성비, 언어능력, 자음정확도 및 gross motor function classification system (GMFCS)에 따른 특성을 제시하였다.
표 1. 경직형과 불수의운동형 뇌성마비 아동의 특성

Table 1. Demographic characteristics of children with cerebral palsy by group

\begin{tabular}{c|c|c}
\hline & 경직형 $(\mathrm{n}=26)$ & 불수의운동형 $(\mathrm{n}=8)$ \\
\hline 평균연령(표준편차) & $7.39(2.28)$ & $6.87(2.58)$ \\
\hline 연령범위 & $4 \sim 12$ & $4 \sim 12$ \\
\hline 남: 녀 & $21: 5$ & $6: 2$ \\
\hline 언어능력 & & \\
정상범주 & 6 & 2 \\
지체 & 20 & 6 \\
\hline 자음정확도(\%) & $49.4(43.27)$ & $32.19(42.06)$ \\
\hline GMFCS & & \\
I & 1 & 0 \\
II & 10 & 1 \\
III & 2 & 0 \\
IV & 1 & 6 \\
V & 12 &
\end{tabular}

GMFCS, gross motor function classification system.

\section{2. 연구방법}

\subsection{1. 실험절차}

음성자료의 수집을 위해 선행연구(Jeong et al., 2011; Park et al. 2004)와 같이 아동에게 모음 ‘아’를 3 번 발성하도록 하였다. 발성을 녹음하기 전에 연구자는 아동이 모방할 수 있도록 시범 을 보여주었고, 아동이 바른 자세로 앉은 상태에서 평상시에 말 하는 편안한 소리크기로 최대한 길게 발성하도록 설명해 주었 다. 발성의 녹음은 디지털 녹음기(ICD-UX512F, SONY)를 사용 하였고, 입과 녹음기 간에 약 $10 \mathrm{~cm}$ 의 거리를 두고 녹음하였다. 두 집단의 발성강도 평균은 경직형은 $60.16 \mathrm{~dB}$, 불수의운동형은 $58.32 \mathrm{~dB}$ 이었다.

\subsection{2. 자료분석}

녹음된 모음발성을 음향학적으로 분석하기 위해 뇌성마비 (Nam \& Kwon, 2009; Pennington et al., 2018), 말운동장애(Bang et al., 2013) 및 음성장애(Lathadevi \& Guggarigoudar, 2018; Oguz et al., 2007) 집단을 대상으로 한 선행연구들을 참조하여 Praat 음성분석 프로그램(version 6.0.30)을 사용하였다.

MPT는 선행연구(Park et al., 2004)와 동일하게 3 개의 음성 파 일 가운데 MPT가 최대인 파일을 선택하여 분석하였다. MPT의 분석은 Praat에서 시각적으로 제시되는 음향 파형이 시작하는 부분과 끝나는 부분을 지정하여 소수점 두 자리까지 측정하였 다. 음향학적 측정치의 분석을 위해서 안정구간 1.5 초 구간을 선정하여 분석하였고(Shim et al., 2014), 안정구간이 1.5초 미만 인 경우에는 분석에서 제외하여 22명을 대상으로 측정하였다 (경직형 17명, 불수의운동형 5명). 수치는 Pulses 메뉴의 voice report에서 F0, Jitter(local), Shimmer(local), NHR(mean)을 사용하 였다. 음도분석에서 음도 배증(pitch doubling)과 음도 반감(pitch halving)과 같은 오류를 제거하기 위해 하한값을 $220 \mathrm{~Hz}$ 로 설정 하여 분석하였다(Park, 2008). 또한 성인에 비해 짧은 성도와 높 은 주파수를 보이는 점을 고려하여(Yoon \& Kim, 2015), 최대 포 먼트 주파수를 8,000 Hz로 설정하여 측정하였다(Boersma \& 


\subsection{3. 통계분석}

뇌성마비 유형 간 음향학적 차이를 분석하기 위해 두 독립표 본 $t$-검정을 실시하였고, 등분산 가정이 충족되지 않는 변인인 Shimmer는 Welch-Aspin 검정을 실시하였다. 본 연구의 자료는 IBM SPSS Statistics version 23(IBM, Armonk, NY, USA)을 이용 하여 분석하였다.

\section{3. 연구결과}

3.1. 뇌성마비 유형별 MPT 의 비교

표 2에 제시된 바와 같이, 뇌성마비 두 유형 간 MPT는 유의한 차이를 보였다 $(p<.05)$. 즉, 경직형보다 불수의운동형의 MPT가 유의하게 짧았다.

표 2. 경직형와 불수의운동형 뇌성마비 아동의 MPT 결과 Table 2. MPT in children with spastic and dyskinetic cerebral palsy

\begin{tabular}{|c|c|c|c|}
\hline & 경직형 $(\mathrm{n}=26)$ & 불수의운동형 (n=8) & $t$-value \\
\hline MPT (sec) & $3.92(3.21)$ & $2.09(1.06)$ & $1.942^{*}$ \\
\hline
\end{tabular}

3.2. 뇌성마비 유형별 음향학적 측정치(F0, Jitter, Shimmer, NHR)의 비교

뇌성마비 유형별 F0, Jitter, Shimmer, NHR은 표 3에 제시하였 다. $\mathrm{F} 0$ 는 집단 간에 유의한 차이가 없었다 $(p>.05)$. 그러나 평균 비교에서는 불수의운동형의 기본주파수가 경직형에 비해 다소 높았다. Jitter에서도 뇌성마비 유형 간 유의한 차이가 없었으나 ( $p>.05)$ 경직형에 비해 불수의운동형의 Jitter가 약간 높게 나타 났다. Shimmer에서는 유형 간에 유의한 차이가 있었고( $p<.05)$, 불수의운동형이 경직형에 비해 유의하게 높았다. NHR은 뇌성 마비 유형 간에 유의한 차이가 없었으나 $(p>.05)$, 경직형보다 불 수의운동형의 NHR이 높은 경향을 보였다.

표 3. 경직형과 불수의운동형 뇌성마비 아동의 F0, Jitter, Shimmer, NHR 결과

Table 3. F0, jitter, shimmer and NHR in children with spastic and dyskinetic cerebral palsy

\begin{tabular}{c|c|c|c}
\hline & 경직형 $(\mathrm{n}=17)$ & 불수의운동형 $(\mathrm{n}=5)$ & $t$-value \\
\hline $\mathrm{F} 0(\mathrm{~Hz})$ & $287.44(77.29)$ & $299.47(67.10)$ & -.340 \\
\hline Jitter $(\%)$ & $.70(.52)$ & $.80(.30)$ & -.439 \\
\hline Shimmer $(\%)$ & $4.35(2.25)$ & $6.95(4.21)$ & $-1.924^{*}$ \\
\hline NHR $(\mathrm{dB})$ & $.05(.08)$ & $.07(.08)$ & -.207 \\
\hline
\end{tabular}

${ }^{*} p<.05$.

NHR, noise to harmonic ratio.

\section{3. 뇌성마비 유형별 F1, F2 의 비교}

표 4에 제시한 바와 같이, F1은 뇌성마비 유형 간에 유의한 차 이가 없었으나( $p>.05)$, 경직형이 불수의운동형보다 더 높게 나
직형에 비해 불수의운동형의 측정치가 높았다.

표 4. 경직형과 불수의운동형 뇌성마비 아동의 $\mathrm{F} 1, \mathrm{~F} 2$ 결과

Table 4. Results of F1 and F2 in children with spastic and dyskinetic cerebral palsy

\begin{tabular}{c|c|c|c}
\hline & 경직형 $(\mathrm{n}=17)$ & 불수의운동형 $(\mathrm{n}=5)$ & $t$-value \\
\hline $\mathrm{F} 1(\mathrm{~Hz})$ & $929.29(275.86)$ & $884.99(117.68)$ & .796 \\
\hline $\mathrm{F} 2(\mathrm{~Hz})$ & $1,527.81(246.92)$ & $1,680.15(274.75)$ & -1.264 \\
\hline
\end{tabular}

\section{4. 논의 및 결론}

본 연구는 생활연령 만 4 12세의 경직형과 불수의운동형 뇌 성마비 아동을 대상으로 두 유형 간 모음의 음향학적 파라미터 에서 차이가 있는지 알아보고자 하였다. 연구결과에 따른 논의 는 다음과 같다.

\section{1. 뇌성마비 유형별 MPT 의 차이}

뇌성마비 유형 간에 MPT는 유의한 차이가 있었고, 경직형에 비해 불수의운동형의 모음연장발성길이가 더 짧게 나타났다. 이는 불수의운동형이 경직형보다 호흡조절능력이나 호흡능력 이 더 저하되어 있음을 반영하는 결과이다.

본 연구에서 불수의운동형의 $\mathrm{MPT}$ 가 경직형보다 짧은 것은 불수의운동형 뇌성마비 아동에서 나타나는 불수의적이고, 불 규칙적인 신체 움직임과 관련이 있을 것으로 보인다. Kim(1999) 은 불수의운동형 뇌성마비 화자는 호흡주기와 상관없이 불규 칙한 복근 활동이 나타난다고 하였는데, 이러한 문제로 인해 발 성개시와 지속 과정에서 방해를 받기 때문에 MPT가 길게 지속 되기 어려웠을 것으로 사료된다. 즉 모음연장발성을 시작하거 나 유지하는 과정에서, 호기근육이나 성대근에서의 불수의적인 움직임으로 인해 연장 발성 도중에 갑자기 발성이 멈출 수 있기 때문에 경직형에 비해 더 짧은 MPT를 보인 것으로 생각된다.

연구에 참여한 불수의운동형 뇌성마비 아동은 모음연장발성 과제를 수행하는 과정에서 경직형에 비해 발성이 끊기는 행동 이 더 빈번하게 나타났다. $\mathrm{Nam}(2015)$ 이 제시한 바와 같이 호흡 관련 근육들의 움직임이 불수의적으로 일어나기 때문에 잦은 흡기를 보이기도 하였고, 가청흡기(audible inspiration) 즉 호흡 이 부족하여 숨을 들이쉬는 소리(Suh \& Kim, 2006)가 청지각적 으로 관찰되기도 하였다. 따라서 이러한 요인들이 불수의운동 형의 MPT 수행에 있어 부정적인 영향을 미쳤을 것으로 보인다.

선행연구에서도 경직형에 비해 불수의운동형에서 호흡문제 가 더 뚜렷하게 나타난다고 보고하고 있다(Hardy, 1983; Love, 2000; Salmon \& Charron, 1998). 불수의운동형의 호흡속도는 경 직형에 비해 더 빠르고(Hardy, 1983), 흡기예비용적도 적으며, 역호흡도 나타나기 때문이다(Hardy, 1983; Workinger, 2005). 이 러한 불규칙한 호흡 패턴(Lee \& Kim, 1999)과 폐활량 감소가 불 수의운동형의 MPT를 제한하는 요인이 되었을 것으로 사료된다. 
4.2. 뇌성마비 유형별 음향학적 측정치(F0, Jitter, Shimmer, NHR)의 차이

경직형과 불수의운동형 뇌성마비 아동의 $\mathrm{F} 0$ 는 통계적으로 유의한 차이가 없었다. 그러나, F0 평균값에서는 경직형에 비해 불수의운동형이 다소 높게 나타났다. 이러한 결과는 선행연구 (Lee, 2004)와 유사하다. 이는 불수의운동형이 경직형에 비해 F0 가 더 높다고 한 Duffy(1954)의 주장과 같다. F0는 초당 성대의 진동횟수를 반영하는 것으로 F0가 높으면 청지각적으로 더 고 음으로 들리게 된다. F0는 성대의 길이, 질량, 탄성과 관련이 있 는데(Yoon, 2019), 경직형에 비해 불수의운동형에서 성대근육 이 더 긴장된 상태로 산출되었기 때문으로 추측된다.

뇌성마비 아동과 일반아동 간 비교연구(Park et al., 2007)에서 도 두 집단의 $\mathrm{F} 0$ 를 비교했을 때 유의미한 차이는 없으나, 뇌성 마비 아동이 더 높은 양상을 보인다고 하면서 음성의 불안정성 을 알기 위해서는 기본주파수의 평균뿐만 아니라 기본주파수 의 표준편차에 대한 평가를 병행하는 것이 후두기능의 정확한 평가에 도움이 된다고 보고한 바 있다. 본 연구에서 추가적으로 기본주파수의 표준편차를 비교해 보았을 때, 불수의운동형은 $36.23 \mathrm{~Hz}$ 이고 경직형은 $22.11 \mathrm{~Hz}$ 로 불수의운동형이 더 큰 편차 를 보이는 것을 확인할 수 있었다.

Jitter에서도 두 유형 간에 통계적으로 유의한 차이가 나타나 지 않았다. 하지만 평균값에서는 불수의운동형의 측정치가 약 간 높았다. Jitter는 주기 간 주파수변동률로 음도변이의 규칙성, 불규칙성을 상대적으로 평가하는 변인이며(Park et al., 2004; Park et al., 2007) 성대진동의 조절과 관련이 있다(Yoon, 2019). 본 연구의 결과는 경직형에 비해 불수의운동형에서 성대진동 이 더 불규칙적이고, 안정적인 성대조절이 상대적으로 어렵다 는 것을 나타낸다. 이를 청지각적으로 분석하면 강도파열 양상 이 불수의운동형에서 더 많이 나타난다고 언급한 바와 같다 (Nam, 2015).

뇌성마비 유형 간에 Shimmer 측정치에서는 통계적으로도 유 의한 차이가 있었다. 이러한 두 유형 간 차이는 불수의운동형에 서 진폭의 변이성이 경직형에 비해 유의하게 높다는 것을 나타 낸다. 즉 음성강도를 일정하게 유지하는 것이 어렵다는 것을 반 영한다(Yoon, 2019). 이러한 결과는 불수의운동형에서 음성강 도가 불규칙적이고(Kim, 1999), 음성크기의 급작스러운 변화가 나타나는 것(Lee \& Kim, 1999)과 관련이 있다. 음성강도의 크기 와 안정성을 유지하기 위해서는 성문하압을 통한 공기압의 크 기(Hegde, 1995)와 조절된 호기를 통한 부드러운 공기의 흐름이 요구되는데(Pennington et al., 2018), 불수의운동형은 후두기류 의 밸빙이 불안정하기 때문에 소리 크기가 가변적으로 나타나 는 것이다(Workinger, 2005). 이는 불수의운동형은 경직형에 비 해 폭발적인 음성을 산출하고, 말소리 강도가 갑자기 변한다는 선행연구의 결과를 지지한다(Kim, 1999).

또한 본 연구에서 청지각적으로 젖은 음성(wet voice), 발성에 서 그렁거림을 동반하는 아동은 Shimmer 측정치도 높게 나타났 으며, 경직형에 비해 불수의운동형에서 더 많이 관찰할 수 있었 다. 이러한 젖은 음성은 흡인을 보이는 삼킴장애환자의 경우
(Kang et al., 2018)에도 다양한 음향학적 변수와 관련이 있는데, Shimmer도 그 관련 변수 가운데 하나라고 보고하고 있다. 또한 $\operatorname{Nam}(2015)$ 의 연구에서도 이러한 청지각적 특성이 불수의운동 형에서 가장 심하게 나타난다고 언급하고 있다.

$\mathrm{NHR}$ 에서는 두 유형 간에 유의한 차이가 없었으나 평균값에 서는 불수의운동형이 약간 높게 나타났다. NHR은 소음 대 배음 의 비율을 의미하는데, $70 ~ 4,500 \mathrm{~Hz}$ 사이의 배음과 $1,500 \sim 4,500$ $\mathrm{Hz}$ 사이의 비정상 배음 간 비율의 평균치이다(Park et al., 2004). 호흡과 발성의 조절과 협응의 문제는 소음에 대한 낮은 배음의 음성 신호로 나타난다(Fox \& Boliek, 2012; Patel, 2003). 불수의 운동형에서는 발성 동안에 갑자기 호흡이 끊기거나, 호흡과 발 성 간 조절이 원활하지 않아 흡기 동안에 발성이 나타나기도 하 였는데, 이러한 요인이 호흡뿐만 아니라 NHR 측정치에도 부정 적인 영향을 미쳤을 것으로 판단된다. 또한 NHR은 후두내부근 의 작용과 관련이 있어 이 근육이 적절하게 작동하지 못할 때는 쥐어짜거나 기식화된 음성을 산출하게 된다. 본 연구의 대상아 동 가운데 경직형 아동에서 쥐어짜는 발성을 보이기도 하였지 만, 불수의운동형 아동에서는 기식성의 거친 발성을 산출하는 경우가 많았다. 이러한 음성적 특성이 $\mathrm{NHR}$ 에서 높은 수치를 나 타내는 것으로 보인다.

그러나 Jitter, Shimmer, NHR 측정치에서 불수의운동형의 수 치가 더 높게 나타난 본 연구의 결과는 Lee(2004)의 연구와는 일 치하지 않는 결과이다. 즉 6 11세의 뇌성마비 아동을 대상으로 한 선행연구(Lee, 2004)에서는 음향학적 측정치에서 두 유형 간 통계적 차이가 없었고, 평균비교에서도 경직형의 수치가 더 높 게 나타났다. 이러한 차이는 유형 간 연구대상의 수, 연령 범위, 성비 및 중증도 등이 달랐기 때문에 결과에 영향을 미쳤을 것으 로 추측된다. 또한 Nam \& Kwon(2009)의 연구에서도 Jitter의 평 균값이 경직형에서 더 높게 나타났다. 선행연구(Nam \& Kwon, 2009)에서는 연령범위가 9 39세로 성인도 포함되어 있는데, 본 연구에서는 4 12세의 뇌성마비 아동 가운데 변성기 발성을 보 이지 않는 아동으로 제한하여 변성기 이후의 주파수 변화를 최 대한 통제하였다. 뇌성마비 아동과 성인 간에 음성문제의 양상 은 연령이 증가함에 따라 차이가 날 수도 있다고 하였는데 (Jeong \& Sim, 2017), 이렇듯 연령의 편차로 인해 다른 결과를 나 타낸 것으로 사료된다.

$\mathrm{F} 0$ 는 신경계 손상으로 인한 마비말장애의 감별진단에 효과적 이지 못하다고 알려져 있지만(Kent et al., 1999), Jitter, Shimmer, $\mathrm{NHR}$ 의 측정치는 병리적 음성의 주요한 파라미터로 사용된다. Jitter, Shimmer 및 NHR의 수치가 낮을 때 맑은 음성, 소음성이 없는 음성으로 지각하는데(Park et al., 2007), 본 연구에서는 경 직형에 비해 불수의운동형에서 더 높은 측정치를 나타내었다. 이는 불수의운동형 뇌성마비 아동은 충분하고 안정적인 호흡 유지에 어려움을 갖고 있고, 후두조절이 적절하게 이루어지지 않기 때문에 경직형에 비해 더 불안정한 음성양상을 나타내는 것으로 보여 진다(Zwirner et al., 1991). 따라서 본 연구의 결과는 불수의운동형 뇌성마비아동은 말을 개시할 때 호흡주기와 음 성강도가 더 불규칙해지고(Lee \& Kim, 1999), 호흡과 발성기관 
간의 부조화로 균일한 호기가 이루어지지 않기 때문에 말산출 에 부정적인 영향을 미칠 수 있다는 선행연구의 주장을 지지한 다(Lee \& Kim, 1999).

\section{3. 뇌성마비 유형별 $\mathrm{F} 1, \mathrm{~F} 2$ 의 차이}

뇌성마비 유형별로 $\mathrm{F} 1$ 의 차이를 알아본 결과, 통계적으로 유 의한 차이가 없었다. 그러나 $\mathrm{F} 1$ 의 평균값에서는 불수의운동형 보다 경직형이 약간 더 높은 측정치를 보였다. 이러한 결과는 경직형과 불수의운동형의 성도모양이 다소 달랐을 것으로 추 정할 수 있다. $\mathrm{F} 1$ 은 구강부가 좁아질수록 감소하게 되는데 (Yang, 1998), 이는 턱이 더 많이 닫힌 상태에서 조음이 이루어 졌다는 것을 의미한다. 따라서 경직형에 비해 불수의운동형에 서 턱관절의 운동범위가 좁아 구강공명강이 감소하였다는 것 을 반영한다. 불수의운동형에서는 조음 시에 과도한 개구반응 이 나타나기도 하지만 이는 불수의적으로 나타나는 양상이고, 수의적인 발성을 할 때는 오히려 턱의 개방범위나 운동범위가 좁은 상태에서 조음하는 것으로 추측할 수 있다.

뇌성마비 유형 간에 F2에서도 유의미한 차이가 없었으나, 불 수의운동형의 측정치가 더 높게 나타났다. F2는 혀의 전방성과 관련이 있고, 혀의 위치가 전방으로 향할수록 커지며(Peterson, \& Barney, 1952; Yang, 1998), 후설음일수록 감소한다(Seong, 2004). 따라서 불수의운동형 뇌성마비 아동이 모음 ‘아' 산출 시 에 혀의 위치가 더 앞쪽으로 향한 상태에서 산출되었다는 것을 반영한다. 뇌성마비 아동 가운데 특히 말명료도가 매우 저하된 경우에는 혀 내밀기(tongue thrust)가 나타나는 경우가 많고, 혀 가 입술 앞으로 전방화되는 경향을 보인다(Jeong \& Sim, 2015). 혀의 위치는 신생아기에는 상대적으로 앞쪽에 있다가 2 세 이후 기능적으로 균형을 갖추면서 치조부위에 위치하게 된다(Peng et al., 2004). 혀의 운동기능이 충분히 성숙하지 못한 경우 혀 내 밀기 같은 비정상적 구강패턴이 지속되면서 원활한 구강운동 을 방해하므로 말산출에 부정적인 영향을 미치게 된다(Jeong \& $\operatorname{Sim}, 2015)$. 따라서 혀의 전후 운동기능은 경직형에 비해 불수의 운동형에서 더 저하되어 있을 것으로 추측된다.

본 연구에서 제시된 $\mathrm{F} 1$ 과 $\mathrm{F} 2$ 의 측정치는 경직형이 불수의운 동형에 비해 모음산출이 더 정확하고(Platt et al., 1980), 불수의 운동형에서 모음오류가 더 많다고 한 선행연구(Sim \& Park, 1998)의 결과를 반영한다. Kent \& Netsell(1978)은 불수의운동형 에서 턱의 움직임이 과도하고, 혀의 위치가 부적절하다고 하였 는데, 본 연구결과로 제시된 측정치를 보면 후설 저모음인 '아' 산출 시 불수의운동형은 턱의 개방범위는 경직형에 비해 더 제 한적이고, 혀는 더 전방화된 상태에서 산출하여 더 부정확하게 조음하였을 것으로 판단된다.

$\mathrm{F} 1$ 과 F2 측정치가 시사하는 바는 뇌성마비 아동을 대상으로 실시한 구강운동능력 향상을 위한 중재연구를 통해서도 확인 할 수 있다. 모음 ‘아' 산출과제에서 중재 전에 비해 중재 후에 $\mathrm{F} 1$ 은 높아지고, $\mathrm{F} 2$ 는 낮아지면서 수치가 변화되는 양상을 보여 준다(Kim \& Paek, 2017). 이는 구강운동프로그램을 통해 턱의 위치, 입술모양의 유지, 혀의 구강 내 안정성 및 위치 조절 등의
구강기능이 향상될 때 모음의 변별산출이 더 향상된다는 것을 시사한다.

자음정확도로 비교해 보아도 경직형(49.4\%)에 비해 불수의 운동형(32.19\%)의 수치는 더 낮은데, 정확한 조음산출을 위한 구강운동능력이 불수의운동형에서 더 저하되어 있음을 반영한 다. 즉, 턱의 가동 범위가 좁고, 혀의 위치나 운동성도 제한적이 기 때문에 말산출을 위한 적절한 구강운동능력이 저하되어 경 직형에 비해 더 낮은 자음정확도를 보이는 것으로 판단된다.

본 연구를 통해 불수의운동형 뇌성마비 아동은 경직형에 비 해 더 짧은 호흡을 나타내고, 진폭변동률이 높으며, 턱과 혀의 운동기능이 상대적으로 저하되어 있음을 확인할 수 있었다. 이 러한 결과는 불수의운동형 뇌성마비 아동을 위한 중재 목표 선 정 시에는 특히 호흡기능 강화와 음성의 안정성 확보 및 구강운 동기능을 향상시켜 줄 수 있는 중재전략이 필요함을 시사한다. 또한 청지각적인 평가와 함께 음향학적 평가를 함께 실시함으 로써 오류 원인을 분석하고, 그 결과를 수량화하여 제시함으로 써 중재의 객관성과 정확성을 높여줄 수 있을 것으로 사료된다. 따라서 본 연구의 결과는 경직형과 불수의운동형 뇌성마비 아 동의 모음 산출특성을 파악하고, 중재전략을 수립하는데 필요 한 정보를 제공해 줄 수 있을 것이다.

본 연구의 제한점은 첫째, 뇌성마비 유형 가운데 실조형은 연 구에 참여하지 않았다. 실조형 유형이 상대적으로 적은 비율을 차지하기는 하지만 후속 연구에서 다양한 유형을 대상으로 한 비교연구가 이루어진다면 보다 세밀한 정보를 제공해 줄 수 있 을 것이다. 둘째, 모음 ‘아만을 분석대상으로 하였다. 다음 연구 에서는 다양한 모음에 따른 음향학적 특성과 차이를 알아볼 필 요가 있다. 셋째, 본 연구는 뇌성마비 유형별 음향학적 차이를 확인하는 것을 목적으로 하여 청지각적 특성과의 관련성에 대 한 연구는 진행하지 않았다. 후속연구에서 이들 두 변인 간의 관련성에 대해 알아본다면 보다 유익한 연구가 될 것으로 생각 된다.

\section{References}

Ahn, H. Y. (1995). Assessment of voice. Seoul, Korea: Jin Soo.

Bang, Y. I., Min, K., Shon, Y. H., \& Cho, S. R. (2013). Acoustic characteristics of vowel sounds in patients with Parkinson disease. Neuro Rehabilitation, 32(3), 649-654.

Bhuta, T., Patrick, L., \& Garnett, J. D. (2004). Perceptual evaluation of voice quality and its correlation with acoustic measurements. Journal of Voice, 18(3), 299-304.

Boersma, P., \& Weenink, D. (2014). Praat: Doing phonetics by computer (version 6.0.30) [Computer program]. Retrieved from http://www.praat.org

Boone, D. R., McFarlane, S. C., \& Berg, S. L. V. (1988). The voice and voice therapy (4th ed.). London, UK: Prentice Hall.

Brockmann, M., Storck, C., Carding, P. N., \& Drinnan, M. J. (2008). Voice loudness and gender effects on jitter and shimmer in healthy 
adults. Journal of Speech, Language, and Hearing Research, 51(5), 1152-1160.

Duffy, R. F. (1954). An analysis of the pitch and duration characteristics of the speech of cerebral palsied individuals (Doctoral dissertation). Purdue University, West Lafayette, IN.

Farmer, A., \& Lencione, R. M. (1977). An extraneous vocal behavior in cerebral palsied speakers. British Journal of Disorders of Communication, 12(2), 109-118.

Fox, C. M., \& Boliek, C. A. (2012). Intensive voice treatment (LSVT LOUD) for children with spastic cerebral palsy and dysarthria. Journal of Speech, Language, and Hearing Research, 55(3), 930-945.

Fry, D. B. (1979). The physics of speech. Cambridge, MA: Cambridge University Press.

Hardy, J. (1983). Cerebral palsy. Englewood Cliffs, NJ: PrenticeHall.

Hegde, M. N. (1995). Introduction to communicative disorders. Austin, TX: Pro-Ed.

Jeong, J. O., Kim, D. Y., Sim, H. S., \& Park, E. S. (2011). The maximum phonation time and temporal aspects in Korean stops in children with spastic cerebral palsy. Phonetics and Speech Sciences, 3(1), 135-143.

Jeong, P. Y., \& Sim, H. S. (2015). The influence of chewing ability on speech intelligibility in children with spastic cerebral palsy. Special Education Research, 14(1), 63-80.

Jeong, P. Y., \& Sim, H. S. (2017). The effect of voice quality on speech intelligibility in children with spastic cerebral palsy. Phonetics and Speech Sciences, 9(4), 129-136.

Kang, Y. A., Koo, B. S., Kwon, I. S., \& Seong, C. J. (2018). Acoustic analysis of wet voice among patients with swallowing disorders. Phonetics and Speech Sciences, 10(4), 147-154.

Kent, R. D., \& Netsell, R. (1978). Articulatory abnormalities in athetoid cerebral palsy. Journal of Speech and Hearing Disorders, 43(3), 353-373.

Kent, R. D., Weismer, G., Kent, J. F., Vorperian, H. K., \& Duffy, J. R. (1999). Acoustic studies of dysarthric speech: Methods, progress, and potential. Journal of Communication Disorders, 32(3), 141-186.

Kim, E. K. (1999). Speech breathing and swallowing-ventilation interaction in athetoid cerebral palsy (Master's thesis). Ewha Womans University, Seoul, Korea.

Kim, M. J., Pae, S., \& Park, C. I. (2007). Assessment of phonology and Articulation for children $(A P A C)$. Incheon: Human Brain Research \& Consulting Co.

Kim, S. H., \& Paek, H. H. (2017). Effect of treatment on oral motor for children with spastic cerebral palsy. Journal of Korea Entertainment Industry Association, 11(1), 211-218.

Kim, Y. T., Hong, G. H., Kim, K. H., Jang, H. S., \& Lee, J. Y. (2010).
Receptive \& Expressive Vocabulary Test (REVT). Seoul: Seoul Community Rehabilitation Center.

Kudrjavcev, T., Schoenberg, B. S., Kurland, L. T., \& Groover, R. V. (1983). Cerebral palsy trends in incidence and changes in concurrent mortality. Neurology, 33(11), 1433-1438.

Ladefoged, P. (2006). A course in phonetics (4th ed.). Wadsworth, $\mathrm{OH}$ : Cengage Learning.

Ladefoged, P., \& Broadbent, D. E. (1957). Information conveyed by vowels. The Journal of the Acoustical Society of America, 29(1), 98-104.

Lathadevi, H. T., \& Guggarigoudar, S. P. (2018). Objective acoustic analysis and comparison of normal and abnormal voices. Journal of Clinical and Diagnostic Research, 12(12), 1-4.

Lee, C. K., \& Kim, E. K. (1999). Respiration patterns and abdominal muscle activities during speech production in athetoid cerebralpalsied patients. Journal of Korean Academy of Rehabilitation Medicine, 23(5), 926-932.

Lee, O. B., Park, S. H., \& Jeong, O. R. (2002). The acoustic characteristics of vowels in the patients with spastic dysarthria. Journal of Speech-Language \& Hearing Disorders, 9(2), 171-177.

Lee, S. A. (2004). Acoustic characteristics of children with spastic and athetoid cerebral palsy (Master's thesis). Hallym University, Chuncheon, Korea.

Love, R. J. (2000). Childhood motor speech disability. Boston, MA: Allyn \& Bacon.

Marks, N. C. (1974). Cerebral palsied and learning disabled children. Illinois, IL: Charles C Thomas Publisher.

Martin, D., Fitch, J., \& Wolfe, V. (1995). Pathologic voice type and the acoustic prediction of severity. Journal of Speech and Hearing Research, 38(4), 765-771.

Maryn, Y., Corthals, P., De Bodt, M., Van Cauwenberge, P., \& Deliyski, D. (2009). Perturbation measures of voice: A comparative study between multi-demensional voice program and Praat. Folia Phoniatrica et Logopaedica, 61(4), 217-226.

Minear, W. L. (1956). A classification of cerebral palsy. Pediatrics, 8 , 841-852.

Nam, H. W. (2015). The auditory-perceptual characteristics of respiration and phonation by the types of cerebral palsy in the reading. Journal of Psychology and Behavior, 7(1), 31-45.

Nam, H. W., \& Kwon, D. H. (2009). A comparative study of the characteristics of the subsystems for speech production by the types of the cerebral palsy. Journal of Speech-Language \& Hearing Disorders, 18(2), 17-50.

Nordberg, A., Miniscalco, C., \& Lohmander, A. (2014). Consonant production and overall speech characteristics in school-aged children with cerebral palsy and speech impairment. International Journal of Speech-Language Pathology, 16(4), 386-395.

Oguz, H., Demirci, M., Safak, M. A., Arslan, N., Islam, A., \& Kargin, 
S. (2007). Effects of unilateral vocal cord paralysis on objective voice measures obtained by Praat. European Archives of OtoRhino-Laryngology, 264(3), 257-261.

Park, E. S., Rha, D. W., Chung, H. I., Park, J. E., Nam, H. S., \& Kim, M. J. (2007). Acoustic analysis of vowel sound in children with spastic cerebral palsy. Journal of the Korean Academy of Rehabilitation Medicine, 31(1), 103-108.

Park, J. E., Park, E. S., \& Kim, H. H. (2004). A study of acoustic characteristics of vowel in preschool cerebral palsy children with spastic diplegia. Communication Sciences and Disorders, 9(2), 116-128.

Park, J. Y., \& Seong, C. J. (2018). The implementation of children's automated formant setting by Praat scripting. Phonetics and Speech Sciences, 10(4), 1-10.

Park, S. J. (2008). A validity study of formant analysis of vowel errors of children: Focused on vowel /u/. Journal of Speech \& Hearing Disorders, 17(3), 117-131.

Patel, R. (2003). Acoustic characteristics of the question-statement contrast in severe dysarthria due to cerebral palsy. Journal of Speech, Language and Hearing Research, 46(6), 1401-1415.

Peng, C., Jost-Brinkmann, P., Yoshida, N., Chou, H., \& Lin, C. (2004). Comparison of tongue functions between mature and tongue thrust swallowing and ultrasound investigation. American Journal of Orthodontics and Dentofacial Orthopedics, 125(5), 562-570.

Pennington, L., Lombardo, E., Steen, N., \& Miller, N. (2018). Acoustic changes in the speech of children with cerebral palsy following an intensive program of dysarthria therapy. International Journal of Language \& Communication Disorders, 53(1), 182-195.

Peterson, G. E., \& Barney, H. L. (1952). Control methods used in a study of the vowels. The Journal of the Acoustical Society of America, 24,175-814.

Pharoah, P. O. D., Cooke, T., Rosenbloom, I., \& Cooke, R. W. I. (1987). Trends in birth prevalence of cerebral palsy. Archives of Disease in Childhood, 62(4), 379-384.

Plaat, L. J., Andrews, G., Young, M., \& Quinn, P. T. (1980). Dysarthria of adult cerebral palsy: I. Intelligibility and articulatory impairment. Journal of Speech, Language and Hearing Research, 23(1), 28-40.

Sawashima, M. (1966). Measurements of the phonation time. Japanese Journal of Logopedics and Phoniatrics, 7, 23-29.

Seong, C. J. (2004). An acoustic analysis on the Korean 8 monophtongs-with respect to the acoustic variables on the F1/F2 vowel space-. The Journal of the Acoustical Society of Korea, 23(6), 454-461.

Shim, S. Y., Kim, H. H., Kim, J. O., \& Shin, J. C. (2014). Difference in voice parameters of MDVP and Praat programs according to severity of voice disorders in vocal nodule. Phonetics and Speech Sciences, 6(2), 107-114.

Sim, H. S., \& Park, J. E. (1998). A study of the vowel production ability of cerebral palsied children. Korean Journal of Communication Sciences and Disorders, 3(1), 68-83.

Solomon, N. P., \& Charron, S. (1998). Speech breathing in able-bodied children and children with cerebral palsy. American Journal of Speech, Language Pathology, 7(2), 61-78.

Suh, M. K., \& Kim, H. H. (2006). Auditory-perceptual variables of speech evaluation in dysarthria literature. Speech Sciences, 13(3), 197-207.

Workinger, M. S. (2005). Cerebral palsy resource guide for speechlanguage pathologists. Clifton Park, NY: Thomson Delmar Learning.

Workinger, M. S., \& Kent, R. D. (1991). Perceptual analysis of the dysarthrias in children with athetoid and spastic cerebral palsy. In C. A. Moore, K. M. Yorkston, \& D. R. Beukelman (Eds.), Dysarthria and apraxia of speech: Perspectives on management (pp. 109-126). Baltimore: Paul H. Brookes.

Yang, B. G. (1998). A study on vowel formant variation by vocal tract modification. Speech Sciences, 3(1), 83-92.

Yoon, K., \& Kim, S. (2015). A comparative study on the male and female vowel formants of the Korean corpus of spontaneous speech. Phonetics and Speech Sciences, 7(2), 131-138.

Yoon, S. Y. (2019). Normative data for voice parameters in Korean females aged between 20 and 59 years. Journal of Language Sciences, 26(1), 291-310.

Yumoto, E., Sasaki, Y., \& Okamura, H. (1984). Harmonics to noise ratio and psychological measurement of the degree of hoarseness. Journal of Speech, Language and Hearing Research, 27(1), 2-6.

Zwirner, P., Murry, T., \& Woodson, G. E. (1991). Phonatory function of neurologically impaired patients. Journal of Communication Disorders, 24(4), 287-300.

\section{- 정필연 (Pil Yeon Jeong)}

이화여자대학교 아동발달센터 연구원 서울특별시 서대문구 성산로 533

Tel: 02-3277-3268

Email:jpy@ewha.ac.kr 관심분야: 뇌성마비, 말명료도, 말운동장애

- 심현섭 (Hyun Sub Sim) 교신저자 이화여자대학교 대학원 언어병리학과 교수 서울특별시 서대문구 이화여대길 52

Tel: 02-3277-3538

Email:simhs@ewha.ac.kr 관심분야: 유창성장애, 음성장애, 말명료도 


\title{
경직형과 불수의운동형 뇌성마비아동의 /아/ 모음 음향학적 비교
}

\author{
정 필 연 $\cdot$ 심 현 섭 ${ }^{2}$ \\ ${ }^{1}$ 이화여자대학교 아동발달센터, ${ }^{2}$ 이화여자대학교 언어병리학과
}

\begin{abstract}
국문초록
본 연구의 목적은 경직형과 불수의운동형 뇌성마비 아동의 음향학적 특성에서 차이가 있는지 알아보는 것이다. 연 구대상은 만 4 12세의 뇌성마비 아동 34 명이 참여하였다(경직형 26 명, 불수의운동형 8 명). 연구과제는 모음 ‘아' 연 장발성하기이고, Praat을 사용하여 MPT, F0, Jitter, Shimmer, NHR과 F1, F2를 측정하였다. 두 유형 간 음향학적 차이 를 알아보기 위해 두 독립표본 $t$-검정과 등분산가정이 충족되지 않는 경우 Welch-Aspin 검정을 사용하여 통계분석 을 실시하였다. 연구결과, 첫째, 경직형 뇌성마비아동에 비해 불수의운동형에서 유의하게 낮은 MPT를 나타내었 다. 둘째, Shimmer에서 불수의운동형의 측정치가 유의하게 높았다. 셋째, F1과 F2에서는 두 유형 간에 유의한 차이 를 보이지 않았다. 이러한 결과는 경직형에 비해 불수의운동형의 호흡능력과 호흡조절능력이 더 제한적이고, 음성 의 불안정성과 불규칙성도 더 많이 나타난다는 것을 시사한다. 본 연구의 결과는 뇌성마비 유형 간 말운동통제능 력의 차이를 확인하고, 유형에 따른 중재계획을 수립하는데 필요한 정보를 제공해 줄 수 있을 것이다.
\end{abstract}

핵심어: 뇌성마비, MPT, Jitter, Shimmer, noise to harmonic ratio (NHR), 포먼트 주파수

\section{참고문헌}

강영애, 구본석, 권인선, 성철재 (2018). 삼킴장애 환자의 wet voice 관련 음향학적 분석. 말소리와 음성과학, 10(4), 147-154. 김민정, 배소영, 박창일 (2007). 아동용 발음평가 $A P A C)$. 인천: 휴 브알앤씨.

김숙희, 백현희 (2017). 경직형 뇌성마비 아동의 구강운동 치료 효과. 한국엔터테인먼트산업학회논문지, 11(1), 211-218.

김영태, 홍경훈, 김경희, 장혜성, 이주연 (2010). 수용·표현어휘 력 검사 $R E V T)$. 서울: 서울장애인종합복지관.

김은경 (1999). 불수의 운동형 뇌성마비에서 호흡이 언어장애와 연하곤란증에 미치는 영향․ㅏ이화여자대학교 석사학위논문.

남현욱(2015). 읽기과제에서의 뇌성마비 유형별 호흡 및 발성의 청지각적 특성. 심리행동연구, 7(1), 31-45.

남현욱, 권도하 (2009). 뇌성마비 유형별 구어산출 하위체계 특성 비교. 언어치료연구, 18(2), 17-50.

박성지 (2008). 아동 모음 오류의 포먼트 분석의 타당성에 관한 연 구 -/u/ 모음을 중심으로-. 언어치료연구, 17(3), 117-131.

박은숙, 나동욱, 정호익, 박지은, 남희승, 김민준 (2007). 경직형 뇌성마비 환아의 모음 산출의 음향음성학적 분석. 대한재활 의학회지, 31(1), 103-108.

박지연, 성철재 (2018). Praat을 이용한 아동 포먼트 자동 세팅 스 크립트 구현. 말소리와 음성과학, 10(4), 1-10.

박지은, 박은숙, 김향희 (2004). 학령전기 경직형 하지마비 아동
이 산출한 모음의 음향음성학적 특징. 언어청각장애연구, 9(2), 116-128.

서미경, 김향희 (2006). 마비말장애 연구문헌에서 살펴본 말평가 의 청지각적 요소. 음성과학, 13(3), 197-207.

성철재 (2004). 한국어 단모음 8개에 대한 음향분석-F1/F2 모음공 간에서의 음향변수를 중심으로-. 한국음향학회지, 23(6), 454-461.

심상용, 김향희, 김재옥, 신지철 (2014). 성대결절 중증도에 따른 MDVP와 Praat 프로그램 별 파라미터 차이. 말소리와 음성과 학, 6(2), 107-114.

심현섭, 박지은 (1998). 뇌성마비 아동의 모음산출에 관한 연구. 언어청각장애연구, 3(1), 68-83.

안회영 (1995). 음성검사법. 서울: 진수출판사.

양병곤 (1998). 성도변형에 따른 모음 포먼트의 변화 고찰. 음성 과학, 3(1), 83-92.

윤규철, 김순옥 (2015). 한국어 자연발화 음성 코퍼스의 남녀 모 음 포먼트 비교연구. 말소리와 음성과학, 7(2), 131-138.

이선아(2004). 경직형 및 무정위운동형 뇌성마비 아동의 음향음 성학적 특성-F0, Jitter, Shimmer, NHR 을 중심으로. 한림대학교 석사학위논문.

이옥분, 박상희, 정옥란 (2002). 경직형 운동구어장애자의 모음의 음향학적 특성. 언어치료연구, 9(2), 171-177.

이청기, 김은경 (1999). 불수의운동형 뇌성마비에서 말하는 동안 의 호흡양상 및 복근의 활동도. 대한재활의학회지, 23(5), 
926-932.

정진욱, 김덕용, 심현섭, 박은숙 (2011). 경직형 뇌성마비 아동의 최대발성지속시간과 파열음 산출 시 조음시간 특성 비교. 말 소리와 음성과학, 3(1), 135-143.

정필연, 심현섭 (2015). 경직형 뇌성마비아동의 씹기능력에 따른 말명료도의 변화. 특수교육, 14(1), 63-80.

정필연, 심현섭 (2017). 경직형 뇌성마비 아동의 음질이 말명료도 에 미치는 영향. 말소리와 음성과학, 9(4), 129-136. 